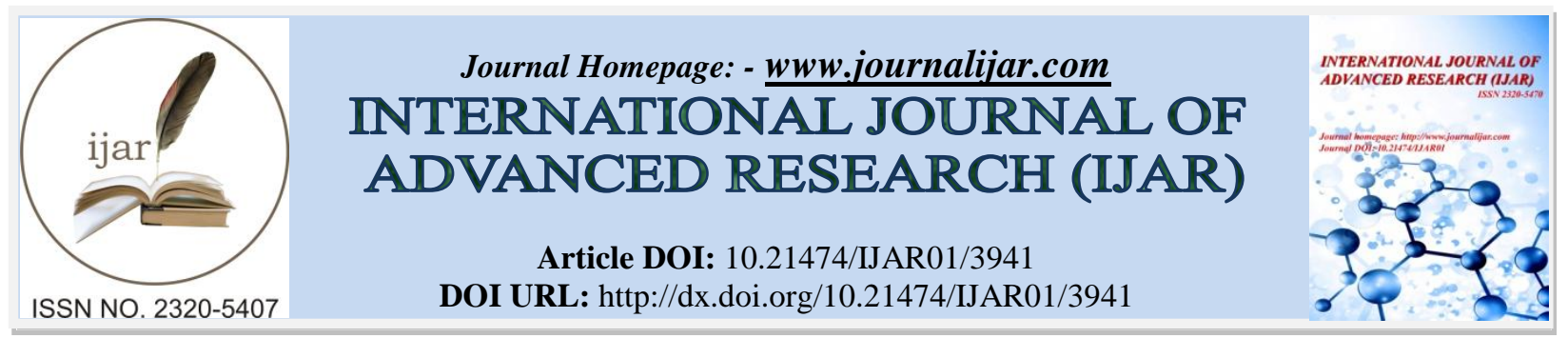

RESEARCH ARTICLE

\title{
EFFECT OF ACUTE TOXICITY OF COPPER ON HISTOPATHOLOGY OF BARBEL OF STINGING CATFISH, HETEROPNEUSTES FOSSILIS (Bloch)
}

\author{
*Sandeep Shukla ${ }^{1}$, Madhu Tripathi ${ }^{1}$ and Sanjive Shukla ${ }^{2}$ \\ 1. Aquatic Toxicology Research Laboratory, Department of Zoology, University of Lucknow, Lucknow-226007 \\ (U.P.), India. \\ 2. P.G. Department of Zoology, B.S.N.V.P.G. College, Lucknow-226001(U.P.), India.
}

\section{Manuscript Info}

\section{Manuscript History}

Received: 05 February 2017

Final Accepted: 08 March 2017

Published: April 2017

Key words:-

Copper sulphate, Heteropneustes fossilis, histopathology, barbel, taste buds.

\begin{abstract}
In spite of being essential trace metal copper imposes marked changes in vital organs of fish at cellular level during acute exposure. Barbels are specialized sensory organs among catfishes having touch and chemoreceptors. Taste buds are one of the important receptors found embedded in the epithelium of barbels which plays important role in olfaction, touch, food detection etc. Copper sulphate induced changes in barbels like inflammation in epidermis, cuticular eruption, atrophy of taste buds, hypertrophy of mucous cells, hypertrophy of club cells, necrosis and degenerative changes in epidermis and taste buds. Basement membrane also showed degenerative changes including thickening and inflammation. Atrophied sensory and taste cells, shrunken taste buds along with the broken opening were noticed. Present study is indicative that copper adversely affects sensory organs at high concentration which inturn disturbs vital activities and survival of fish.
\end{abstract}

Copy Right, IJAR, 2017,. All rights reserved.

\section{Introduction:-}

Heavy metal pollution has been emerged as global environmental problem. Heavy metals due to high solubility, persistence, bioaccumulation and biomagnifications are serious threat to aquatic ecosystem. Heavy metals contaminate aquatic bodies like ponds, pools, lakes, river system by various natural processes as well as due to anthropogenic activities.

Copper, a grey listed heavy metal (Meson, 1996), is known to be essential to sustain normal life activities but in excess it is a potential toxicant affecting icthyo fauna either directly or indirectly (Gardner and La Roche 1973; James and Sampth, 1995; Khangroot and Rathore, 1999; Lodhi et al 2006; Lodhi, 2009). In aquatic ecosystem copper compounds are used as algaecide and fungicide. Copper is an essential element involved in numerous physiological processes but is also a known, potent toxicant especially to aquatic animals.

Today copper is used as a water purifier, algaecide, fungicide, nematocide, molluscicide, and as an anti-bacterial and anti-fouling agent. Copper also displays potent anti-viral activity. Copper impose wide range of adverse effect on fish and other aquatic organisms. The exposure of fish to chemical contaminants is likely to induce a number of lesions in different organs (Bucher and Hofer, 1993; Poleksic et al., 1994; Brusl'e et al., 1996) in order to determine the effect of pollution. Histopathology is an important component of several measures of an organism's health and

Corresponding Author:- Sandeep Shukla. 1243

Address:- Aquatic Toxicology Research Laboratory, Department of Zoology, University of Lucknow, Lucknow-226007 (U.P.), India. 
histopathological markers have been recommended for field application, more often as a generalized, non-specific response to several stressful stimuli (Teh et al., 1999).

Fish and other fish products are preferable food products due to their nutritional value and easy availability in fresh water as well as marine water. In states like Uttar Pradesh fresh water fishes are part of human diet. Among fresh water fishes cat fishes like Heteropneustes fossilis are widely used in aquaculture due to their hardy nature, easy availability and maintenance. Fish are sensitive to changes in water quality hence serve as good bio-indicator of aquatic pollution.

Due to paucity of literature, economic importance of fish and present work was taken into consideration to evaluate copper sulphate toxicity on histological alterations in barbel of Heteropneustes fossilis, a common cherished table fish of Indian sub continent.

\section{Material and Methods:-}

Adult healthy fresh water stinging cat fish Heteropneustes fossilis were collected from river Gomti and other reservoirs in and around Lucknow, with the help of local fishermen and brought to laboratory (N-26 $51^{\prime} 59^{\prime \prime}$, E$\left.80^{\circ} 56^{\prime} 17^{\prime \prime}\right)$ in large plastic containers. Collected fish were treated with $0.1 \% \mathrm{KMnO}_{4}$ solution and acclimatized to laboratory condition according to guidelines of APHA et al (1998), for 15-20 days until fish start normal feeding, in cemented tanks.

Healthy fishes of almost same size $(16 \pm 2 \mathrm{~cm})$ and weight $(20 \pm 2.5 \mathrm{~g})$ were transferred to glass aquaria of 50 liter capacity containing 30 liter fresh dechlorinated water. Electric air pumps and stone diffusers were used to maintain dissolved oxygen and temperature of water. Stock solution of copper (II) sulphate $\left(\mathrm{CuSO}_{4} .5 \mathrm{H}_{2} \mathrm{O}\right.$; M.wt. $=299.68$; A.R. grade, Manufactured by: Qualikems Fine Chemicals Pvt. Ltd. New Delhi-110060 India.) was prepared by dissolving calculated amount of salt in double distilled water.

For acute toxicity test fish were subjected to test concentration of 96 hours $\mathrm{LC}_{50}(219.81 \mathrm{mg} / \mathrm{l})$ to evaluate histopathological changes in target organs. Separate controls were used for test and observations were made simultaneously in test and control fish under similar environmental conditions.

Observations were taken at the intervals of 24, 48, 72 and 96hr. For histopathological studies control and experimental fish were anesthetized in MS-222. Tissue were carefully dissected out, washed in normal saline, fixed in alcoholic Bouin's fluid for 24 hours followed by washing in $70 \%$ alcohol. For histopathology, tissue were dehydrated and embedded in paraffin wax. Serial sections were prepared and flattened on albumenized microscopic slides. Sections were stained with Harris' Haematoxylin and Eosin, and mounted in Canada balsam. Prepared slides were studied and photographed under Olympus trinocular research microscope comparing with controls.

\section{Results:-}

Barbels of $H$. fossilis plays important role as a sensory organ in its physiological activities. Copper sulphate imposed mort histological alterations in the barbel, a sensory organ of fish, during acute exposure. Barbel is covered by multilayered epidermis with pear shaped taste buds (Sato and Kapoor, 1957) along with mucous and club cells (Whitter, 1989) on the inner side of dermis collagenous connective tissue, blood vessels, chromatophores are localized (Sato, 1977; Sato and Kapoor, 1957; Kasherwani, 2006).

After $24 \mathrm{hr}$ exposure heavy coating of mucous on epithelium, inflammation and cuticular eruption were observed at places. Hypertrophy in mucous cells was observed along with shrinkage of taste buds.

After $48 \mathrm{hr}$ of exposure epidermal eruptions were noticed, due to that most of the taste buds were found exposed. Chloride cells were found hypertrophied at most of the places. Necrotic and degenerative changes were observed at some places. After $72 \mathrm{hr}$ of exposure hypertrophy of Chloride cells was more prominent. Breaking of outer cuticle and degenerative changes in epidermis were more severe. Taste buds were found shrunken with atrophied sensory cells and supporting cells. Basement membrane was thickened and lesser number of chromatophores was observed in dermis. 
After $96 \mathrm{hr}$ of exposure the covering epidermis lost its cellular organization, due to necrotic and degenerative changes and found cracked at most places. Mucous cells showed hypertrophy. Sensory cells as well as supporting cell of taste buds showed severe necrotic and degenerative changes, therefore found broken and shrunken. The apical region of gustatory cells was opened and scattered in comparison to close and tight association of control. Basement membrane showed breaking and inflammation at most of the places. Number of chromatophores in dermis was found reduced along with breaking of muscle bands.

Plate 1:-
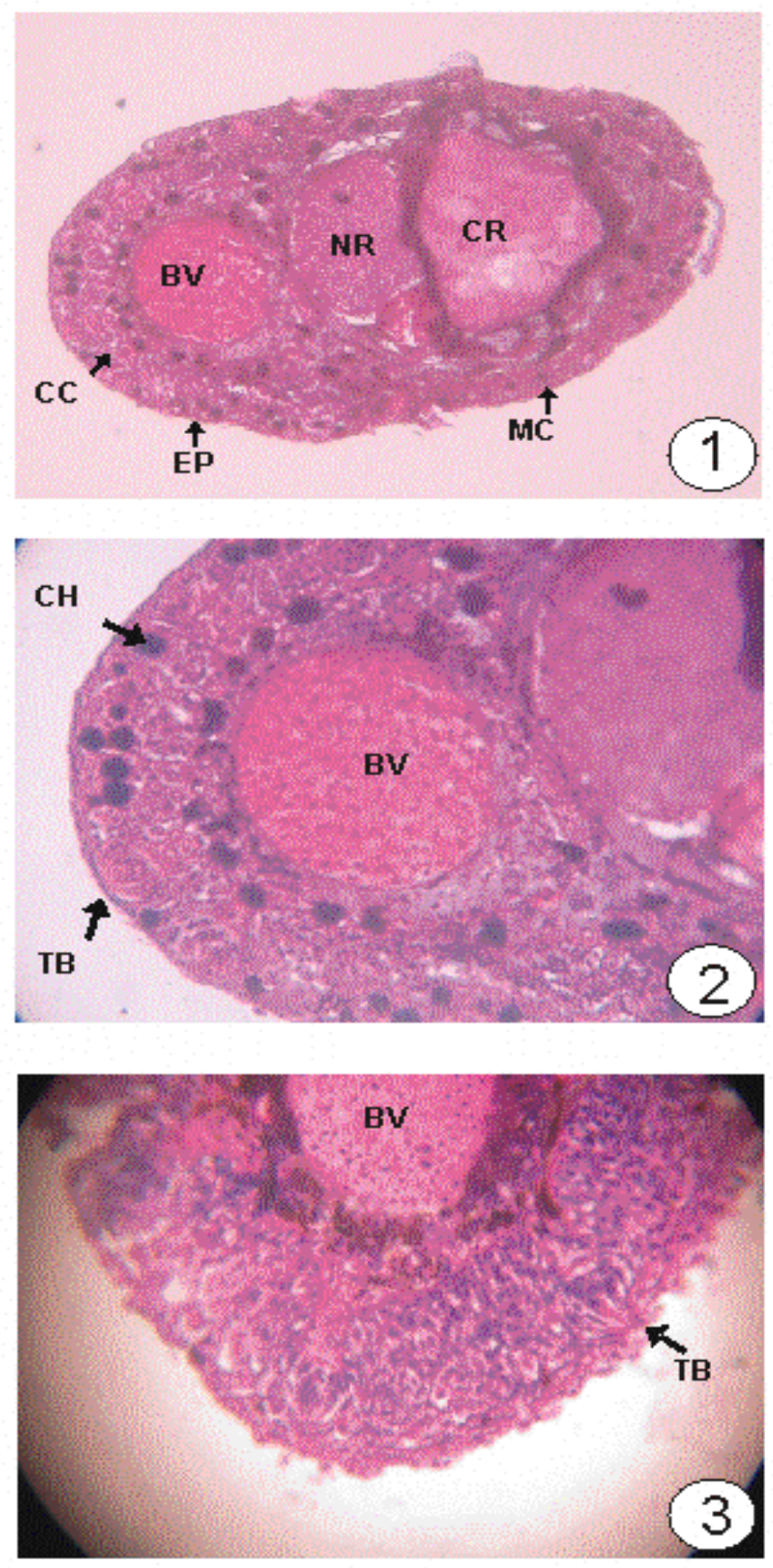

$\mathrm{BV}=\mathrm{Blood}$ vessel; $\mathrm{CC}=$ Chloride cell; $\mathrm{CH}=$ chromatophores;

$\mathrm{CR}=$ Cartilage; $\mathrm{EP}=$ Epithelium; $\mathrm{NR}=\mathrm{Nerve}$;B=Taste buds

Explanation of figures (Fig. 1-3): Photomicrograph of T.S. of Barbel (Control) (X100, X200 and X400 respectively) 


\section{Plate 2:-}
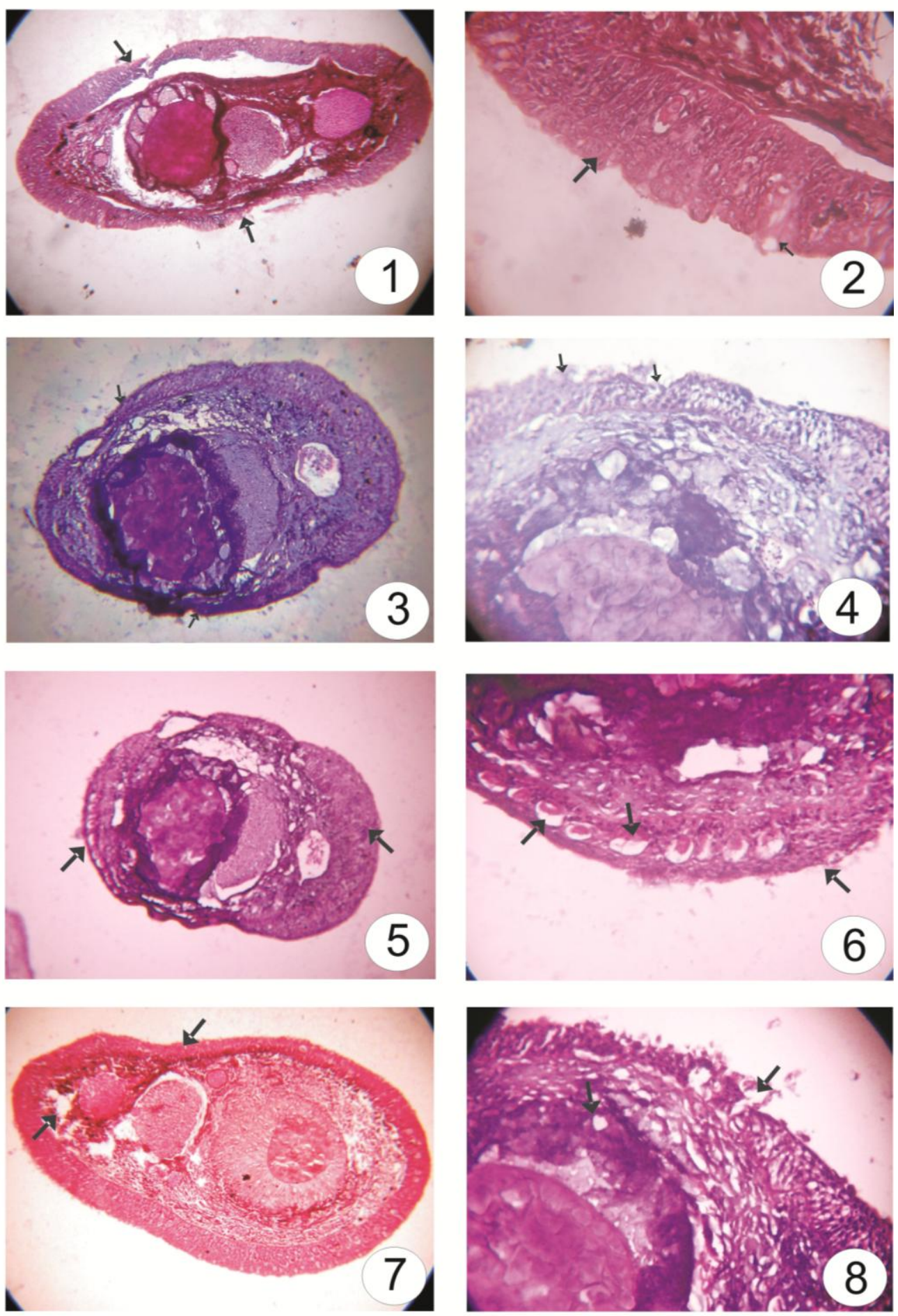

Explanation of figure (Fig. 1-8): Photomicrograph of T.S. of Barbel after acute exposure of copper sulphate: (Fig. 1\&2) After 24hr; (Fig. 3\&4) After 48 hr; (Fig. 5\&6) After 72 hr; (Fig. 7\&8) After 96 hr. (Fig. 1, 3, 5 \& 7 X200; 2, 4, 6 \& 8 X400) 


\section{Discussion:-}

Almost similar changes were reported by various workers (Wyllies, 1981; Iger and Bonga, 1993). Almost similar changes due to apoptosis and cell death were recorded in common crab skin after Cd exposure (Igar and Bonga, 1993), who were suggestive that peroxidised positive mucous cells which contribute to glucocalyx formation may be cause of degenerative changes in epidermis. The necrosis and apoptosis of taste buds might be a reason of accelerated turnover filamental cells as reported in various heavy metals (Iger, 1992; Iger and Bonga, 1993). Mitogenic effect of heavy metals might be responsible for hyperplasia and hypertrophy in epidermal cells, taste buds and club cells (Eaton, 1974). The degenerative and necrotic changes of the epidermal cells as observed in present study may probably be due to apoptosis leading to necrotic changes as it is well known that apoptosis leads to ageing and extortion of epidermal cells (Kasherwani, 2006).

The degeneration of club cells and migration towards epidermal surface as observed in present study were also reported in fishes after Cd exposure (Iger and Bonga, 1993). The club cells in the skin provide an alarm reaction to the metal exposure (Pffer, 1977). The rupturing of epithelial cells after metal toxicity leads to decrease secretory activity which may due to erosion, shedding and renewal of epithelium by new cells. These newly exposed cells might have taken some time for being ready for secretion (Rajan and Banerjee, 1991).

Excessive mucous secretion, degenerative changes, extortion and reduction in number of mucous cells in the epithelium as observed in present study may be due to direct cytotoxic action of metal or shortening of life span of mucous cells. The dead cell layer of the epidermis act as secondary protective device to prevent the entry of heavy metals and shed off after some time. Similar type of degeneration of cells have been noticed in gills and skin of $H$. fossilis after mercuric chloride exposure (Rajan and Banerjee, 1991) and after cadmium chloride exposure (Kasherwani, 2006). A thick coating and encapsulation of taste buds is formed due to release of club cells and other cells in the epidermis. Similar kind of encapsulation of taste buds has been reported by Rajan and Banerjee (1991) after mercuric chloride exposure and Kasherwani (2006) after cadmium chloride exposure.

The basement membrane below epithelial layer act as a barrier and regular passage of cells and chemicals. It also regulates morphogenesis and wound healing, serving as an attachment site for epithelial cells and other cells (Whitear, 1986; Roberts and Bullock, 1978). The inflammation and damage to the basement membrane results in epithelial damage thereby destroy the taste buds leading change to some of the important behavioural patterns like loss of olfaction, feeding and schooling of fish.

Taste buds are one of the important receptors found embedded in the epithelium of barbels which plays important role in olfaction, touch, food detection etc. (Sonarraj et al., 1995). The histological symptoms like necrosis of Taste buds is one of the common feature affecting olfaction of fishes, which results in loss of food detection capacity and loss of school formation (Sonarraj et al., 1995; Bardach et al., 1965; Ghatak and Konar, 1990; Vincent et al., 2002; Berntssen et al., 2003). Histological alterations in taste buds along with degenerative changes showed functional impairment of chemoreceptors and impaired food detection capacity after copper sulphate exposure (Hasther, 1957). Similar kind of degenerative changes in Taste buds prior to damage of epithelial cells have been reported in case of detergents as well as other toxicants (Bardach et al., 1965; Loroche, 1972).

Findings of these workers are suggestive that these receptors i.e. Taste buds are more sensitive than rest of the receptors of the epithelium. Similar type of findings have been reported in alteration in normal histology of taste buds after exposure of various toxicants (Bardach et al., 1965; Loroche, 1972; Rajan and Banerjee, 1991).

\section{Conclusion:-}

Findings of present study are indicative that copper at higher concentrations affects chemo sensation of fish, which in turn affects physiology, behaviour, reproduction and survival of economically important fish like H. fossilis.

\section{Acknowledgement:-}

Authors are thankful to the Head, Department of Zoology, University of Lucknow for providing necessary lab facilities, and also grateful to Prof. U. D. Sharma, Retd. Professor, Department of Zoology, University of Lucknow, Lucknow (U.P.) India for valuable suggestions and guidance. 


\section{References:-}

1. Ahmad, M., and Datta Munshi, J.S. (1987). Variation of copper toxicity on the fingerlings of fresh water Indian major carps, Catla catla (Ham.) and Labeo rohita (Ham.) Biol. Bull India. 9:185-189.

2. APHA, AWWA, WPCF. (1998). Standard methods for the examination of water and waste waters. $20^{\text {th }}$ Edn., APHA, Washington.

3. Bardanch, J.E.; Fiyiya, M. and Hall, A. (1965). Detergents: Effects on the senses of the fish, Ictalurus natalis (Leseur). Science. 148:1605-1607.

4. Brusl’e, J.; Gonz’alez, I. and Anadon, G. (1996). The structure and function of fish liver. In: Fish Morphology (J. S. D. Munshi and H. M. Dutta, eds.), Sci. Publishers Inc.; New York.

5. Bucher, F. and Hofer, R. (1993). The effects of treated domestic sewage on three organs (gills, kidney, liver) of brown trout (Salmo trutta). Water Res 27, 255-261.

6. Eaton, J.G. (1974). Chronic toxicity to the blue gill, Lipomis macrochirus. Trans. Amer. Fish. Soc. 103(4):729735 .

7. Gardner, G.R. and La Roche, G. (1973). Copper induced lesions in esturine teleost. J. Fish Res. Bd. Can.30: 363-368.

8. Ghatak, D.B. and Konar, S.K. (1990). Acute toxicity of heavy metals cadmium, pesticide DVP, detergent Parnol-J and petroleum product n-haptane on fish, plankton and worm. Environ. Ecol. 8(4): 1239-1248.

9. Igar, Y. (1992). Adaptive reactions in the skin of the common carp (Cyprinus carpio) under the impact of wounding and ecological factors, Ph. D thesis Herbrew Univ. of Jerusalem, Jerusalem, Israel.

10. Igar, Y. and Wendelaar Bonga, S.E. (1993). Cellular responses of the skin of crap (Cyprinus carpio) exposed to acidified water. Cell Tissue Res. 13:23-27.

11. Iger, Y.; Balm, P.H.; Jenner, H.A. and Wendelaar Bonga, S.E. (1995). Cortisol induces stress related change in the skin of rainbow trout (Oncorhynchus mykiss). General and Comparative Endocrinology. 97:188-198.

12. James, R. and Sampth, K. (1995). Sublethal effects of mixtures of copper and ammonia on selected biochemical and physiological parameters in cat fish Heteropneustes fossilis (Bloch). Bull. Environ. Contem. Toxicol. 55:187-194.

13. Kasherwani, D. (2006). Studies on freshwater fish with special reference to effects of heavy metals PhD Thesis, University of Lucknow, Lucknow, India.

14. Khangaroot, B.S. and Rathore, R.S. (1999). Copper exposure reduces the resistance of the cat fish Saccobranchus fossilis to Aeromones hydrophila infection. Bull. Environ. Contem. Toxicol. 62: 490-495.

15. Khangarot, B.S., and D. M. Tripathi. (1991). Changes in humoral and cell-mediated immune responses and in skin and respiratory surfaces of catfish, Saccobranchus fossilis, following copper exposure. Ecotox. Environ. Safety 22:291-308.

16. Lindesjoo, E. and Thulin, J. (1984). Histopathology of skin and gills of fish in pulp mill effluents. Diseases of Aquatic Organisms. 18: 81-93.

17. Lodhi, H.S (2009). Effect of copper sulphate on the kidney or green gland of fresh water prawns (CrustaceaDecapoda). Poll. Res. 28 (2): 187-192.

18. Lodhi, H.S.; Khan, M.A.; Verma, R.S. and Sharma U.D. (2006). Acute toxicity of copper sulphate to fresh water prawns. J. Environ. Biol. 27(3): 585-588.

19. Loroche, G. (1972). Biological effects of short term exposures to hazardous materials. Proceeding of the National Conference of Hazardous Materials Spills.pp-199-201.

20. Mason, C.F. (1996). Biology of fresh water pollution. $3^{\text {rd }}$ Edn. Longman, U.K. pp. 1-4.

21. Pffer, W. (1977). The distribution of fright reaction and alarm substance cells in fishers, Copeia. 635-665.

22. Poleksic, V.; and Mitrovic-Tutundzic, V. (1994). Fish gills as a monitor of sublethal and chronic effects of pollution. In Sublethal and Chronic Effects of Pollutants on Freshwater Fish (R.M“uller and R. Lloyd, eds.) 339-352. FAO, Fishing News Books, Oxford, UK.

23. Rajan, M.T. and T.K. Banerjee (1991). Histopathological changes induced by acute toxicity of mercuric chloride on the epidermis of freshwater catfish Heteropneustes fossilis (Bloch.). Ecotoxicol. Environ. Safe. 22: $139-152$.

24. Roberts, R. J. (1989). The pathphysiology and systemic pathology of teleosts, in Fish Pathology. Roberts, R.J. (Ed.)pp 56-134, Bailliere Tindall, London.

25. Roberts, R. J. and Bullock, A. M. (1978). Spearman, R.I.C. and Riley, P.A. (Eds.) pp 13-27, Academic Press, London.

26. Sato, M. (1977). Histology of barbels of Blepsias cirrhaus dracicus (Cottdate). Japanese J. Icthyol. 23:220-224.

27. Sato, M. and Kapoor, B. G. (1950). Histological observations on the barbels of India freshwater fishes, Alaska codfish and Podothecus acipenserinus. Annotationes Zoologicae Japaneses. 30:156-161. 
28. Sornaraj, R.; Baskaran, P. and Thanalakshmi, S. (1995): Effects of heavy metal on some physiological response of air breathing fish, Channa punctatus (Bloch). Environ. Ecol. 13(1):202-207.

29. Teh, S. J.; Clark, S. L.; Brown, C. L.; Luoma, S. N. and Hinton, D. E. (1999). Enzymatic and histopathological biomarkers as indicators of contaminant exposure and effect in Asian clam (Potamocorbula amurensis). Biomarkers. 4: 497-508.

30. Vincent, S.; Ambrose, T. and Selvanayagam, M. (2002). Impact of cadmium on food utilization of Indian major carp, Catla catla (Ham). J. Environ. Biol. 23(2):209-212.

31. Whitear, M. (1989). Merkel cells in lower vertebrates. Arch. Histol. and Cytol. 52:415-422

32. Wyllie, A.H. (1981). Cell death: A new classification separating apoptosis from necrosis. In: Bowen I.D. and Lockshin, R.A. (Eds) Cell death in biology and pathology. Chapman and Hall, London. pp.9-34. 